\title{
THE ART OF ACHIEVING POLITICAL GOALS WITHOUT USE OF FORCE: WAR BY NON- MILITARY MEANS
}

\author{
Veronika STOILOVA
}

\begin{abstract}
Nowadays, the boundaries between war and peace are increasingly blurred. Over the past few years we can observe the appearance of new terms in the field of international relations - 'hybrid war,' 'hybrid conflicts' or 'hybrid threats.' Despite the absence of a generally recognized definition of the concept, its characteristics are close to the definition of terrorism. Some security analysts indicate this type of conflict as a war, combining conventional methods with guerrilla, cyber and information warfare techniques (media and Internet) as well as with non-military actions, which run contrary to international law and aim to achieve specific policy goals.
\end{abstract}

Keywords: hybrid war, geopolitics, global security, defence, non-military means, international conflict.

Approximately two centuries ago, the Prussian military strategist and theorist Carl von Clausewitz wrote that a person could not understand war without understanding the broader political and social importance of the context in which it operated. He stressed that war could never be an isolated act. ${ }^{1}$ While describing the security conditions that existed in the $18^{\text {th }}$ Century Europe, the characterization of Clausewitz on war sounds topical in the $21^{\text {st }}$ Century.

In modern times, the boundaries between war and peace are getting increasingly blurred. Over the past few years, we can observe the appearance of a new term used in the field of international relations - 'hybrid war.' Despite the absence of a generally recognized definition of the concept, its characteristics are close to the definition of terrorism. Some security analysts indicate this type of conflict as a war, combining conventional methods with guerrilla, cyber and information warfare techniques (media and the Internet) as well as with non-military actions, which contradict the international law and whose aim is to achieve specific political goals.

It would not be an exaggeration to say that war is a political instrument of making the other side do what you want it to do. Furthermore, diplomacy and politics on the one 
hand, and warfare on the other, are related in a special way. All wars are political in their purpose and all wars aim to achieve political results. ${ }^{2}$ It should be kept in mind that in some ways, warfare happens when the other things fail. ${ }^{3}$

The profound changes in the relations between states and people, the memories and consequences of the last two World Wars, the difference in the balance of power in the international arena, the impossibility to predict the outcome of a possible global cataclysm - all these provoke a search for new forms of confrontation, which could provide participants in the global politics with desired results without significant losses and significant benefits without binding commitments. This presumption means that all activities may be acceptable when one of the sides aims to win a victorious war.

Hybrid warfare can be defined as a new stage in the development of asymmetric conflicts. People in political circles often put a sign of equality between hybrid war and asymmetric warfare, and sometimes terrorism. In practice, however, the hybrid approach is the next step in the evolution of the armed conflict. As a specific conflict, the hybrid war has attracted the international community's attention during the Second Lebanon War (the so called 'July War') between Israel (military forces) and Hezbollah organization (paramilitary forces with Iranian military support). In this sense, it is important to mention that despite the relatively new sound of the term, the implementation of hybrid tactics is not new. Over the years, they have been used in military operations by many countries. A similar strategy was applied during the Vietnam War, and its primary objective was to deplete the enemy's army. After the Cold War, the hybrid war became an increasingly common practice in view of the fact that waging a conventional war could end up with serious consequences. Therefore, in many cases the country that organizes the hybrid attack uses non-state entities (guerrillas, terrorist organizations, revolutionaries, rebels) as a cover. In the scientific literature, this type of war is called unconventional and, later on, a hybrid war. On the one hand, it is a considerably cheaper strategy and its implementation in practice is better than any conventional army. On the other one, using such a strategy gives the state or non-state actor the option to bypass all international law norms. If it is a country, it would distance itself from the actions of the organization that it has built and maintained in order to realize its (country) interests abroad. If it is a non-state actor, it is anyway not recognized by the international law and, accordingly, may use all conventional or unconventional means available to it.

One of the characteristics of the hybrid wars is the fact that they can combine symmetric and asymmetric instruments of warfare. In this regard, one can say that hybrid conflicts have complete physical and ideological dimension (a struggle against an armed enemy and a struggle for control and support). ${ }^{4}$ Moreover, it destabilizes the state and polarizes the society. 
Like asymmetric conflicts, hybrid war has no clearly defined front line and it is waged by using all military and non-military means that the state or non-state actors have at their disposal: regular army, guerrilla, terrorist tactics and tools, as well as all other non-military methods for exerting influence in a hidden way on the perceptions of the other side. Organizations such as 'Hamas,' 'Hezbollah' and the 'Islamic State' are good examples how without being a state, a non-state actor can create armies and can seek for political representation.

Hybrid warfare is also perceived as a modern form of guerrilla warfare, because it combines both modern technology and classic methods of mobilization. Participants are able to easily switch from conventional to guerrilla tactics, which is often the boundary between guerrilla warfare and terrorism. In this sense, hybrid warfare can be referred to as a category located between conventional and asymmetric warfare. The distinction between asymmetric conflicts and hybrid war is difficult.

The combination of military and non-military actions in hybrid war and the discreet nature of applied tactics do not allow the state against which it is directed to react with force or to request assistance from the international community.

The nature of conflicts is constantly changing. The blurred boundary between war and peace is actually the most dangerous weapon of hybrid threats. In conducting this type of war, the evaluation of the results is of particular importance for its success.

The term 'hybrid war' has not yet been formally introduced. In this sense, an introduction of a new form of war is not justified. Another reason for the lack of definition lies in the inability for security threats to be fully formulated. It is difficult to distinguish between asymmetric conflicts and hybrid war. Moreover, the term causes confusion instead of clarifying the 'reality' of modern warfare.

Some sources indicate that the term 'hybrid war' was used for the first time in 2004 by Australian military analysts. Nevertheless, in 2007 on the occasion of the IsraeliLebanese war, Frank Hoffman attempted to identify some key characteristics of the new hybrid threats in his article "Conflict in the 21st Century: The Rise of Hybrid Wars." According to Hoffman, the hybrid war "incorporates a range of different modes of warfare, including conventional capabilities, irregular tactics and formations, terrorist acts including indiscriminate violence and coercion, and criminal disorder." 5

In the United States some senior military officials used the term 'hybrid warfare' during testimony before the Congress between 2008-2010 to describe the methods used by U.S. adversaries in Iraq and Afghanistan, and what U.S. forces are likely to encounter in future conflicts. ${ }^{6}$ But that was not an attempt to clarify and describe this new challenge as a serious threat for the global peace and security. 
Hybrid threats were described by NATO in 2010 and 2011 as "threats ... posed by adversaries, with the ability to simultaneously employ conventional and nonconventional means adaptively in pursuit of their objectives." All members of the Organization underlined the seriousness of such threats and also expressed the readiness to take all necessary steps to respond to them. Since no one is able to deal with hybrid threats alone, a joint international cooperation is essential.

It was in August 2014 when during its summit in Wales ${ }^{8}$ NATO made the first attempt to analyse the hybrid war in the context of the events in Ukraine. The $2015 \mathrm{Na}-$ tional Military Strategy of the United States recognizes hybrid war as a strategic risk not only for the USA, but for the global security, as well.

On 1 December 2015, during the Meetings of NATO Ministers of Foreign Affairs, a new strategy on hybrid warfare was approved. ${ }^{9}$ This is not just an attempt to identify the hybrid war as a global peace and security threat, but an evidence of its existence in the contemporary political reality.

Hybrid warfare is characterized by the use of misinformation so that a suitable situation for the realization of a particular idea is created. In this sense, it is important to note that the information warfare is one of the key elements of the hybrid war. All elements of the 'classic' war are typical for this type of war, plus the availability of information aggression that aims to conquer no territories, but influence people's consciousness, their worldview, beliefs and values. The greatest manifestation of information warfare is the denial of its existence.

There are a lot of events in the world today that serve as evidence that information warfare is an integral part of modern conflicts. Furthermore, information warfare is given a lot of weight - the development of information and communications technologies have created a new peacetime virtual battlefield. In the modern political reality, information warfare could be conducted for a long period not only in peacetime, but in wartime, as well. It is not far from true that information warfare has become highly politicized.

Some say that the hybrid war is a cyber-war, as well. Free dissemination of misinformation bends the truth and confuses people; they lose sight of whom they are actually fighting against. There are a lot of examples of cyber warfare driven by political motivations - the conflicts of former Yugoslavia, South Ossetia, during the Arab Spring, Ukraine, Syria, etc.

Cyber warfare is waged in the cyberspace and includes media and the Internet. In appropriate circumstances, media can have a powerful impact on the political processes in the world. The freedom of the Internet has made the wide public a party of policy discussions and decision-making processes. In this regard, the YouTube effect ${ }^{10} \mathrm{can}$ 
be used as a hybrid war method for exerting influence in a hidden way and also as a non-military means aiming to shape public opinion globally and to achieve specific political results. Used as a tool by the wrong people in the wrong way, it could cause a lot of damage.

Hybrid warfare is a serious threat for the global peace and security because of its unclear borders. Therefore, traditional systems for defence and security find it difficult to detect this type of aggression on time and are not able to respond quickly and adequately. No country is ready to face such a war. Hybrid methods of war affect the principle of state sovereignty, which cannot be protected because of the specificity of the threat. Furthermore, the internationalization of a hybrid conflict threatens the international peace and security through the involvement of terrorist organizations in it. A good example is the situation in Syria and the appearance of the 'Islamic State' with all the methods a terrorist organization applies. Some say that, as a hybrid war tool, the international terrorism is directed to achieve certain political goals. It is not possible for terrorists to wage successfully conventional wars.

The migration crisis caused by the situation in Syria can be observed as a possible threat for the global peace and security. The refugee wave towards Europe is a serious challenge and therefore it should be researched in the context of hybrid war.

Despite the relatively modern sound of the term 'hybrid war,' this partial implementation of hybrid tactics is not new. ${ }^{11}$ Over the years, they have been used in military operations by many countries. The inability for all the security threats to be fully formulated is the reason for the lack of a clear definition of the term.

If the hybrid war's purpose as a whole is to conceal the real intentions of its real participants, it undoubtedly has its undisguised activities utilising globalization - destabilization of different regions through planned revolutions, real or pseudo coups d'état and plots, anti-democratic ambitions of some states for world hegemony, etc.

The ideas developed for the hybrid war implementation into the social reality remind of something that happened in the past. In that regard, it is worth mentioning Hitler's Total war. Was it an early, hybrid form of war, or the current hybrid warfare is just a late form of the former total war? Well, history does not repeat itself, but nothing is completely devoid of continuity.

One of the features of the hybrid warfare in the contemporary political reality is that it leads to decomposition of space and time as an environment and factor in which and through which the international relations evolve. That is also the reason why the international environment is so precarious.

Hybrid warfare is nothing new but it suggests a new approach carefully considered with the hybrid nature of 21 st-century relations. According to some observers, it is 
neither war nor peace. Because of its specificity, it is not easy for one to distinguish whether the hybrid war has a beginning or end. It does not depend on numerous armies, fire superiority or other physical conditions. It also does not conform to the nature of conventional wars. But it has both its military and political side. In this regard, a conclusion could be made that the hybrid war has a decisive role in international politics. All planned political results could be achieved without use of force in peacetime and in wartime, as well.

In a world that changes every day, the threat posed by hybrid warfare is real because no one is prepared for the unexpected. By reason of its unclear borders, the hybrid war has been defined and perceived as a serious threat for the global peace and security. In modern times, territories and borders have become irrelevant, which means that waging a modern war by non-military means is easier and is not limited to the physical battlefield.

\section{References}

1. Carl von Clausewitz, On War (Princeton, NJ: Princeton University Press, 1976), Book 1, chap. 2, 76.

2. Angelo Codevilla, "Political Warfare: Means for achieving political ends," In: Strategic Influence: Public Diplomacy, Counterpropaganda, and Political Warfare, editor J. Michael Waller, (Institute of World Politics Press, 2008), 206-223.

3. Octavian Manea, "Hybrid War as a War on Governance," Interview with Dr. Mark Galeotti, Small Wars Journal, August 21, 2015, accessed June 12, 2018, http://smallwarsjournal.com/jrnl/art/hybrid-war-as-a-war-on-governance.

4. Juliana Geran Pilon, Cultural Intelligence for Winning the Peace, (The Institute of World Politics Press, Washington, 2009), 76

5. Frank Hoffman, Conflict in the 21st Century: The Rise of Hybrid Wars (Arlington, VA: Potomac Institute for Policy Studies, Arlington, VA, 2007), 14.

6. "Hybrid Warfare: Briefing to the Subcommittee on Terrorism, Unconventional Threats and Capabilities, Committee on Armed Services, House of Representatives," GAO-10-1036R (Washington, DC: United States Government Accountability Office, 10 September 2010).

7. Michael Miklaucic, "NATO Countering the Hybrid Threat," NATO Allied Command Transformation, September 23, 2011, https://www.act.nato.int/natocountering-the-hybrid-threat, accessed May 21, 2018.

8. Jakub Kufčák, "NATO after the Wales Summit: Readying the Alliance for the Future," Policy Paper 3/2014 (Prague: Association for International Affairs, Octo- 
ber 2014), www.amo.cz/wp-content/uploads/2015/11/amocz_pp_2014_03.pdf, accessed May 21, 2018.

9. Federica Mogherini, "Press statements by the NATO Secretary General Jens Stoltenberg and the EU High Representative for Foreign Affairs and Security Policy," December 2, 2015.

10. Veronika Stoilova, "You Tube Effect and Its Impact on Global Politics," International conference Knowledge-Based Organization 22, no. 1 (2016): 149-152.

11. "The 'new' type of war that finally has the Pentagon's attention," Washington Post, 3 July, 2015.

\section{About the Author}

Veronika STOILOVA, $\mathrm{PhD}$, is assistant professor in the South-West University "Neofit Rilski," Blagoevgrad, Bulgaria. E-mail: veronikabg@gmail.com. 